\title{
Effect of Fenugreek on Carbohydrate and Lipid Metabolisms of Rats Treated With Cypermethr in Combined With High-Fat-Diet and Low Dosestreptozotosin
}

\author{
Nagwa I. Koteb', Farahat A.F. Foda' ${ }^{1}$, Ibrahim M. Abd El-Aleem', Yasmin E. Abdel-Mobdy²and Tahany A. A. Aly ${ }^{3}$. \\ Agric. Biochem. Dept., Fac. Agric., Banha Univ., Banha, Egypt \\ Department of Economic Entomology Pesticides, Fac. Agric., Cairo, Egypt \\ Regional Center for Food and Feed, Agricultural Res. Center, Giza, Egypt \\ Corresponding author: Nagwa.Ibrahim49@Yahoo.Com
}

\begin{abstract}
The aim of the present study was to use the new model for the type 2 diabetes using high-fat diet (HFD) in combination with low dose of streptozotosin $(\mathrm{STZ}, 35 \mathrm{mg} / \mathrm{kg}$ ) and investgate the influences of cypermethr in (pesticide) toxicity which attenuated by fenugreek soaked seeds, etiolated sprouts (3 days old) and microgreen (10 days old) semi-modified diet (SMD) on experimental rats. From the obtained results, it can be indicated that the high fat feeding in combination with a low doses of STZ together with cypermthrin ingestion increased blood glucose and LDL-c in the paralled with decreasing rats body weight gain. The treatment by fenugreek etiolated sprouts (10\%) semi-modified diet for HFD with STZ as semi-modified diets improved significantly the rats body weight gain (BWG) and lipids profile, while feeding on fenugreek microgreen readjusted significantly blood glucose, BWG, total cholesterol and HDL-c but decreased LDL-c levels. On the other hand, the using of soaked fenugreek seed semi-modified diets increased only BWG but decreased LDL-c. The hyperglycemia increased the total cholesterol content under the treatment with fenugreek microgreen semi-modified diets which showed more pronounced increment in combination with cypermethrin. The accomplished results showed that cypermethrin led to a hyperglycemic activity in HFD/STZ model rats. Soaking fenugreek seeds improved lipid metabolism compared with fenugreek and microgreen which non-toxic in doses given to rats in the present study over 28 days period.
\end{abstract}

Keywords: Cypermethrin, Fenugreek, Etiolated Sprouts, Microgreen, Streptozotocin, Albino rat.

\section{Introduction}

Induced diabetic models, of the experimental rats requires relatively high dose of streptozotocin (STZ> $50 \mathrm{mg} / \mathrm{kg}$ ). Also, the hyperglycemia in these rats following STZ injection is primerly due to the direct pancreatic beta cell destructions and resulting insulin deficiency rather than the consequence of insulin resistance (Shafrir, 2003). Thus, they depict symptoms and characteristics typical more of human type 1 and type 2 and further are not responsive to the effect of anti-diabetic drugs (Portha et al., 1994 and Singh et al., 2013).

In contrast, the rats fed with high-fat diets develop obesity, hyper- insullinemia and insulin resistance and not frank hyperglycemia or diabetes, thus limiting the screening of agents on controlling the blood glucose level (Storlien et al., 1986, Srinivasan et al., 2004 and Abdel-Rahim et al., 2009). Thus the new type 2 diabetic rat mode developed by combining with feeding of high fat diets which produced insulin resistance and low dose of STZ injection. It caused the initial beta cells disfunction and subsequently the frank hyperglycemia (as preferred model) as reported by Srinivasan et al., (2005). Pyrethroid pesticides such as cypermethrin (CM) in increasingly being used indoor pest control because of their high toxicity to insects and low toxicity to mammals. Cypermethrin (CM) is an important type II pyrethroid pesticide (Verschoyle and Aldrige., 1980) used extensively in pest control in the field. Pyrethroids reported to cause hepatotoxicity(Abdel-Mobdy and Abdel-Rahim, 2015).

Animal studies have indicated that increased liver weight and liver function enzymes activity resulted hepatocellular hypertrophy, congestion and other microscopic changes (Schoenig, 1995; Misra and Sharma, 1997 and Ishmael and Litchfield, 1988). In vivo and in vitro studies have shown that CM induces hepatotoxicity and nephrotoxicity in experimental animals. (Manna et al., 2005 and Abdel-Rahim et al., 2009).

Several studies have indicated that pretreatment with antioxidant can ameliorate the toxicity of pyrethroids (Aldana et al., 2001, Giray et al., 2001, Salah et al., 2010 and Abdel-Mobdy and Abdel-Rahim, 2015).

Fenugreek seeds (Trigonella foenum graecum) is one of the oldest medicinal plants dating back to Hippoocrats and ancient Egyptian times (Jensen, 1992). Fenugreek seeds are a rich source of flavonoid compounds and many workers have reported the antioxidant potential of fenugreek (Dixit et al., 2005; Kaviarasan et al., 2006; Randhir et al., 2004, Ravikumar and Anuradha, 1999). Fenugreek contains saponins, glycosides and other beneficial chemical constituents (Naidu et al., 2011) which has pharmaceutical effects on pancreas and other tissues and improves glucose absorption, 
hyperlipidemic states as well as regulates insulin (Raghuram et al., 1994; Prasanna, 2000 and Sauvaire et al., 1998). Sprouting seeds for human consumption has been used for centuries in Egypt and Asian countries to improve food values.In forms of soaking and leaving seeds until they germinate and begin to sprout. This practice was reported to be associated with improvements in the nutritive value of seeds (Abdallah, 2008).

Insulin resistance is often associated with increased triglyceride (TG) and decreased HDL-c concentrations and increased LDL-c practices (Singh et al., 2013).

The aim of the present study was investigated the influences of combination between diabetes, obesity and cypermethrin toxicity as well as evaluated the potentials as beneficial effects of soaked fenugreek seeds, etiolated sprouts and microgreen as semimodified diets on blood glucose and lipid metabolites in normal and diseased intoxicated experimental rats

\section{Material and Methods}

Fenugreek seeds were obtained from Agriculture Research Center, Giza. The seeds were cleaned from all impurities, for boiling soaked seeds (Hulba tea), and for etiolated sprout and microgreen production. Fenugreek etiolated sprout was done in glass jar methods for 3 days old as reported by Abdallah (2008). While fenugreek microgreens were developed in open field and harvested after 10 days old from seed sowing. Bulk of boiling soaked seeds etiolated sprouts and microgreen were air dried for 3 days according to Dzowela et al. (1995) before crushed into powder for rats diets. Streptozotocin (STZ) was obtained from Biomedical, LLC. Palm oil was obtained from local market and cypermethrin formulation (Cyperco $20 \%$ EC) was obtained from the Central Agriculture Pesticides Laboratory, Agriculture Research Center, Dokki-Giza-Egypt.

\section{Experimental animals and diets:}

The present study had been done using 50 male albino Spargue-Dawely rats with weight $140 \pm 10 \mathrm{~g}$. The rats were provided by the animal house of the Egyptian Organization of Biological Products and Vaccines, Egypt. They were raised in the animal house of Biology Laboratory, Faculty of Agriculture, Cairo University, Egypt. The rats were divided into ten equal groups (5 rats each) and housed individually in stainless steel cages with wire mesh bottom and maintained $25 \pm 2{ }^{\circ} \mathrm{C}$, relative humidity of $50-60 \%$ and 12/12 $\mathrm{h}$ light/dark cycle throughout the experiment for a week for laboratory acclimatization. 45rats fed on high fat diets (HFD) which normal standard diet (AIN 76 diet ) with addition $20 \%$ palm oil at the expense of corn oil and corn starch Table (1) ad libilium for the initial week period. After the week of HFD diets, 45 rats were injected intraperiotionally with low dose of STZ $(35 \mathrm{mg} / \mathrm{kg})$. Fenugreek semi-modified diets was prepared by addition of $10 \%$ level of boiling soaked, or etiolated sprouts or microgreen powders at the expense of corn starch as the American Institute of Nutrition Formulation ( Ain-76 diets) (Table 1).

Table 1. Composition diets (g/100 g) based on dry weight

\begin{tabular}{lccc}
\hline Ingredients \% & Control diet & HFD $^{\mathbf{2}}$ & $\begin{array}{c}\text { Fenugreek soaked, etiolated sprouts and } \\
\text { microgreen diets }\end{array}$ \\
\hline Casein & 20 & 20 & 20 \\
Corn starch & 65 & 50 & 40 \\
Mineral mix $^{1}$ & 3.5 & 3.5 & 3.5 \\
Vitamin mix $^{1}$ & 1.0 & 1.0 & 1.0 \\
DL-Methionine & 0.3 & 0.3 & 0.3 \\
Choline & 0.2 & 0.2 & 0.2 \\
Cellulose powder & 5.0 & 5.0 & 5.0 \\
Palm oil & 5.0 & 20 & 20 \\
Fenugreek soaked or etiolated & - & - & 10.0 \\
sprouts or microgeen & - & &
\end{tabular}

\section{Experimental design}

After the initial week period five groups of rats were oral toxified for 28 days according to European Commission, (1996). The 10 groups were detailed as follows:

G1 $\mathrm{P}_{0} \mathrm{~T}_{0}$ : Normal health control rats fed on control diet .

G2 $\mathrm{P}_{0} \mathrm{~T}_{1}$ : HFD/STZ rats fed on HFD diet.

G3 $\mathrm{P}_{0} \mathrm{~T}_{2}$ : HFD/STZ rats treated by soaked seeds semi-modified diet

G4 $\mathrm{P}_{0} \mathrm{~T}_{3}$ : HFD/STZ rats treated by etiolated sprouts semi-modified diet
G5 $\mathrm{P}_{0} \mathrm{~T}_{4}$ : HFD/STZ rats treated by microgreen semimodified diet

G6PT $_{0}$ : Normal rats Fed on standard diet, served as pesticide (cypermethrin $\mathrm{CM}$ ) intoxicated control by ingested with $1 / 10$ of $\mathrm{LD}_{50}$ of the pesticide

G7PT 1 HFD/STZ intoxicated cypermethrin (CM) rats (diseased/intoxicated control)

G8 $\mathrm{PT}_{2}$ : HFD/STZ intoxicated cypermethrin ( CM)rats treated by soaked seeds diets

G9 $\mathrm{PT}_{3}$ : HFD/STZ intoxicated cypermethrin( CM) rats treated by etiolated sprouts diets 
G10 PT 4 : HFD/STZ intoxicated cypermethrin $(\mathrm{CM})$ rats treated by microgreen diets

Blood samples collection and Analytical methods: Blood samples were collected from fasting rats $(12 \mathrm{~h})$ of each group from the retero oribital plexus of veins according to Schermer (1967) after 28 days in clean and sterile and labeled centrifuge tubes. Separating serum immediately was done by centrifugation at 1500xg for $5 \mathrm{~min}$. Blood glucose was determined enzymatic colorimetrically in the serum according to the method of Trinder (1969).The serum total cholesterol (TC), low density lipoprotein cholesterol (LDL-c), and high density lipoprotein cholesterol (HDL-c) and triglycerides (TG) were determined with an automatic analyzer using diagnostic kit for each according to Fossati and Prencipe. (1982) ; Allain et al., (1974); Wieland et al., (1983) and Burstein et al.,(1980) respectively. While glucose was measured according to Hugget and Nixon 1957. Very low-density lipoprotein cholesterol (VLDL-c) was calculated by subdivision $\mathrm{TG} / 5$ according to Fiedewald et al., (1972). The obtained data were statistically analyzed according to the method of Snedecor and Cochran (1980) and LSD $(\mathrm{P}<0.05)$ was used to compare the significant differences between mean of treatments.

\section{Results and discussion}

Concerning blood glucose levels measured before streptozotosin (STZ) injection (0 week) and at the end of the experiment (4 week that the experimental period) are illustrated in Table (2).The obtained results showed slight hyperglycemia for pesticide intoxicated group as comparing with to normal control during the studied period. Also, the achieved data showed body weight gain of normal and intoxicated experimental rats. From the obtained results found that pesticide ingestion significantly decreased the body weight with non-significant effect on body weight gain/100g intial body weight.

Table 2. Effect of cypermethrin pesticide ingestion on blood glucose levels, body weight and body weight gain on experimental rats.

\begin{tabular}{cccccccc}
\hline \multirow{2}{*}{ Paramters } & \multicolumn{2}{c}{ Blood glucose (mg/dl) } & \multicolumn{2}{c}{ Body weight (g) } & \multicolumn{2}{c}{ Body weight gain } \\
\cline { 2 - 8 } Pesticide & $\begin{array}{c}\text { Before } \\
\text { STZ inj. }\end{array}$ & $\begin{array}{c}\text { Final exp. } \\
\text { (4 week) }\end{array}$ & Initial & Final & (g) & $\begin{array}{c}\text { Per 100g } \\
\text { intial body } \\
\text { weight }\end{array}$ & \% \\
\hline $\begin{array}{c}\text { Without pesticide } \\
\text { With pesticide } \\
\text { (cypermethrin) }\end{array}$ & $88.067 \mathrm{~A}$ & $155.70 \mathrm{~B}$ & $173.7 \mathrm{a}$ & $226.04 \mathrm{~A}$ & $52.97 \mathrm{~A}$ & $30.50 \mathrm{a}$ & 100 \\
LSD 0.05 & 87.67A & $186.35 \mathrm{~A}$ & $176.7 \mathrm{a}$ & $207.68 \mathrm{~B}$ & $50.96 \mathrm{~A}$ & $28.84 \mathrm{~b}$ & 95 \\
\hline
\end{tabular}

Means in each column of each group followed by the same letter are not significant different at the 5\% level. $\mathrm{NS}=$ not significant

The high fat diet (HFD) feeding with low STZ in Table (3) showed significant hyperglycemia with fenugreek microgreen(T4) at the end of experiment which amounted to $203.38 \mathrm{mg} / \mathrm{dl}$. The other groups treatments .i.e. with fenugreek etiolated sprouts recorded insignificant inceases in blood glucose levels which ranged between 160.5 and $172.88 \mathrm{mg} / \mathrm{dl}$ after fenugreek microgreen, treatments compared to normal control (148.63 $\mathrm{mg} / \mathrm{dl})$. However, the low dose of STZ (35/mg) slightly produced hyperglycemia as compared with normal control. Similar data was reported by Srinivasan et al., (2005) they found that the high fat diet feeding with low STZ showed increase in the weight gain per $100 \mathrm{~g}$ of intial body weight under the treatment of soaked seeds.

Table 3. Effect of fenugreek semi-modified diets on blood glucose levels, body weight and body weight gain in experimental rats without cypermethrin as pesticide

\begin{tabular}{|c|c|c|c|c|c|c|c|}
\hline \multirow{2}{*}{$\begin{array}{l}\text { Parameter } \\
\text { Diet }\end{array}$} & \multicolumn{2}{|c|}{ Blood glucose (mg/dl) } & \multicolumn{2}{|c|}{ Body weight (g) } & \multirow{2}{*}{$\begin{array}{c}\text { Body } \\
\text { weight } \\
\text { gain (g) }\end{array}$} & \multirow{2}{*}{$\begin{array}{c}\text { B.Wg/100g } \\
\text { initial body } \\
\text { weight }\end{array}$} & \multirow[b]{2}{*}{$\%$} \\
\hline & $\begin{array}{c}\text { Before } \\
\text { STZ inj. }\end{array}$ & $\begin{array}{c}\text { Final exp. } \\
\text { (4 weeks) }\end{array}$ & Initial & Final & & & \\
\hline Standard diet (T0) & $87.17 \mathrm{~A}$ & $148.63 \mathrm{~B}$ & $167.8 \mathrm{AB}$ & $214.10 \mathrm{AB}$ & $46.30 \mathrm{~B}$ & $27.59 \mathrm{C}$ & 100 \\
\hline HFD/STZ (T1) & $88.00 \mathrm{~A}$ & $169.75 \mathrm{~B}$ & $167.5 \mathrm{AB}$ & 199.10B & $31.60 \mathrm{C}$ & $18.87 \mathrm{D}$ & 68 \\
\hline T2 & $87.50 \mathrm{~A}$ & $160.50 \mathrm{~B}$ & $177.1 \mathrm{~A}$ & $227.40 \mathrm{~A}$ & $50.33 \mathrm{~B}$ & $28.42 \mathrm{C}$ & 103 \\
\hline T3 & $88.83 \mathrm{~A}$ & $172.88 \mathrm{~B}$ & 157.1B & $218.50 \mathrm{~A}$ & $61.40 \mathrm{~A}$ & 39.08B & 142 \\
\hline T4 & $87.83 \mathrm{~A}$ & $203.38 \mathrm{~A}$ & $155.0 \mathrm{~B}$ & $225.20 \mathrm{~A}$ & $70.20 \mathrm{~A}$ & $45.29 \mathrm{~A}$ & 164 \\
\hline LSD 0.05 & NS & 27.583 & 26.1 & 26.125 & 13.782 & 6.01 & \\
\hline
\end{tabular}

Means in each column followed by the same letter are not significantly different at the $5 \%$ level.

$\mathrm{NS}=$ not significant 
The interaction between cypermethrin pesticide and HFD/ STZ induction showed significant hyperglycemia either for G9 (HFD/STZ/CM+etiolated sprout semi-modified diet and G10 ( HFD /STZ/CM treated by microgreen semi-modified diet) which those recorded 190.25 and $235.5 \mathrm{mg} / \mathrm{dl}$ respectively for glucose contents of serum, which were significant difference at the other treatment

The interaction between cypermethrin pesticide and HFD/STZ Table (4) also showed the same trend in the body weight gain. However, HFD/STZ without pesticide (G2) and with pesticide (G7) recorded the lowest body weight gain.
The decrease in the body weight gain of HFD/STZ, may be due to the rats catoblism of fats. However, HFD/STZ diabetic rats fed on fenugreek etiolated sprouts and microgreen semi-modified diet showed improvement in body weight gain which may be explained by increased insulin-like compounds and elevated consumption (Amer et al., 2004, Taniguchi et al., 2007 and Tahany, 2015). Mansor et al. (2013) reported that $30 \mathrm{mg} / \mathrm{kg} \mathrm{STZ}$ dose induced weight loss especially the weight gain in the final weeks despite the continuation of the high fat diet, compared with the normal control.

Table 4. Effect of fenugreek semi-modified diets on blood glucose levels, body weight and body weight gain on experimental rats.

\begin{tabular}{|c|c|c|c|c|c|c|c|c|}
\hline \multirow{2}{*}{\multicolumn{2}{|c|}{ parameter }} & \multicolumn{2}{|c|}{ Blood glucose (mg/dl) } & \multicolumn{2}{|c|}{ Body weight (g) } & \multicolumn{2}{|c|}{ Body weight gain } & \multirow[b]{2}{*}{$\%$} \\
\hline & & $\begin{array}{c}\text { Before } \\
\text { STZ inj. }\end{array}$ & $\begin{array}{c}\text { Final } \\
\text { exp. } \\
\text { (4 week) }\end{array}$ & Initial & Final & $(\mathrm{g})$ & $\begin{array}{l}\text { Per 100g } \\
\text { initial body } \\
\text { weight }(g)\end{array}$ & \\
\hline Group 1 & (POT0) & $87.33 \mathrm{a}$ & $140.25 \mathrm{c}$ & $176.4 \mathrm{a}$ & $230.00 \mathrm{ab}$ & $53.60 \mathrm{cb}$ & 30.39 & 100 \\
\hline Group 2 & (POT1) & $88.33 \mathrm{a}$ & $163.50 \mathrm{bc}$ & $174.0 \mathrm{a}$ & 207.60abcd & $33.60 \mathrm{~d}$ & $19.31 \mathrm{f}$ & 64 \\
\hline Group 3 & (POT2) & $87.67 \mathrm{a}$ & $148.00 \mathrm{c}$ & $172.7 \mathrm{a}$ & $232.00 \mathrm{a}$ & $59.25 b$ & $34.31 \mathrm{c}$ & 113 \\
\hline Group 4 & (POT3) & $89.00 \mathrm{a}$ & $155.50 \mathrm{bc}$ & $171.2 \mathrm{a}$ & $231.20 \mathrm{ab}$ & $60.00 \mathrm{~b}$ & $35.05 \mathrm{c}$ & 115 \\
\hline Group 5 & (POT4) & $88.00 \mathrm{a}$ & $171.25 b c$ & $171.0 \mathrm{a}$ & $294.0 \mathrm{ab}$ & $58.40 \mathrm{ab}$ & $34.15 \mathrm{c}$ & 112 \\
\hline Group 6 & (PT0) & $87.00 \mathrm{a}$ & $157.00 \mathrm{bc}$ & $159.2 \mathrm{ab}$ & $198.20 \mathrm{~cd}$ & $39.00 \mathrm{~d}$ & $24.5 \mathrm{e}$ & 81 \\
\hline Group 7 & (PT1) & $87.67 \mathrm{a}$ & $176.00 \mathrm{bc}$ & $161.0 \mathrm{ab}$ & $190.60 \mathrm{~d}$ & $29.60 \mathrm{~d}$ & $18.39 \mathrm{f}$ & 61 \\
\hline Group 8 & (PT2) & $87.33 \mathrm{a}$ & $173.00 \mathrm{bc}$ & $181.4 \mathrm{a}$ & $222.80 \mathrm{abc}$ & $41.40 \mathrm{~cd}$ & $22.82 f$ & 75 \\
\hline Group 9 & (PT3) & $88.67 \mathrm{a}$ & $190.25 b$ & $143.0 \mathrm{~b}$ & $205.80 \mathrm{bcd}$ & $62.80 \mathrm{~b}$ & $43.42 b$ & 145 \\
\hline Group10 & (PT4) & $87.67 \mathrm{a}$ & $235.50 \mathrm{a}$ & $139.0 \mathrm{~b}$ & $221.00 \mathrm{ab}$ & $82.00 \mathrm{a}$ & $58.99 \mathrm{a}$ & 194 \\
\hline LSD0.05 & & NS & 39.02 & 18.44 & 18.47 & 9.74 & 3.26 & \\
\hline
\end{tabular}

Means in each column followed by the same letter are not significantly different at the $5 \%$ level.

$\mathrm{NS}=$ not significant

$\mathrm{P} 0=$ without pesticide. $\quad \mathrm{P}=$ with pesticide $(\mathrm{CM})$.

$\mathrm{T} 0=$ Normale controle. $\quad \mathrm{T} 1=$ High fat diet (HFD).

T2=High fat diet (HFD) +Fenugreek soaked seeds $(10 \%)$.

$\mathrm{T} 3=$ High fat diet (HFD)+Fenugreek etiolated sprout $(10 \%)$.

T4=High fat diet (HFD)+Fenugreek microgreen (10\%).

The feeding of HFD produced rats with insulin resistance syndrome as characterized by the increased body weight (obesity), mild hyperglycemia and compensatory hyperinsullinemia together with reduced glucose disappearance rate a condition similar to prediabetic, insulin resistance states in humans (Reaven and HO, 1991 and Sirinvasan et al., 2004). HFD has been shown to induce insulin resistance by different mechanisms but considered mainly though glucose fatty acid cycle (AbdelRahim et al., 2009). Briefly, the presence of high level of triglycerides due to excess fat intake could constitute as a source of increased fatty acid availability and oxidation. The preferential use of increased fatty acid for oxidation blunts the insulinmediated reduction of hepatic glucose output and reduces the glucose uptake or utilization in skeletal muscle leading to compensatory hyper-insulinemia, a common feature of insulin resistance (Belfiore and Iannello, 1998; Iwanishi and Kobayashi, 1993 and Rosholt and King, 1994). The increased body weight found in HFD rats might be due to the consumption of a diet rich in energy in the form of saturated fats and its deposition in various body fat pads (Srinivasan et al., 2004) and decreased energy expenditure as compared to normal pelts diet-fed animal (Storlien et al., 1986).

Table (5) showed serum lipid profile TC, TG, LDL-c, HDL-c and vLDL-c of the experimental rats ingested with or without cypermethrin pesticide which compared with normal rats. From the obtained results, serum TC, TG, HDL-c and vLDL-c showed insignificant values under the ingestion of $\mathrm{CM}$ as compared with normal control while LDL-c was increased in CM ingested rats $(10.97 \mathrm{mg} / \mathrm{dl})$ compared to that of normal control $(9.55 \mathrm{mg} / \mathrm{dl})$. 
Table 5. Effect of cypermethr in pesticide ingestion on lipid profile of experimental rats

\begin{tabular}{lccccc}
\hline \multicolumn{1}{c}{ Parameter } & $\begin{array}{c}\text { Total cholesterol } \\
\mathbf{m g} / \mathbf{d l}\end{array}$ & $\begin{array}{c}\text { Triglyceride } \\
\mathbf{m g} / \mathbf{d l}\end{array}$ & $\begin{array}{c}\text { HDL-c } \\
\mathbf{m g} / \mathbf{d l}\end{array}$ & $\begin{array}{c}\text { LDL-c } \\
\mathbf{m g} / \mathbf{d l}\end{array}$ & $\begin{array}{c}\text { vLDL-c } \\
\mathbf{m g} / \mathbf{d l}\end{array}$ \\
\hline $\begin{array}{l}\text { Westicide } \\
\text { esticide (cypermethrin) }\end{array}$ & $79.60 \mathrm{~A}$ & $108.05 \mathrm{~A}$ & $48.30 \mathrm{~A}$ & $9.55 \mathrm{~B}$ & $21.61 \mathrm{~A}$ \\
\hline LSD 0.05 & $84.25 \mathrm{~A}$ & $102.85 \mathrm{~A}$ & $47.35 \mathrm{~A}$ & $10.97 \mathrm{~A}$ & $20.57 \mathrm{~A}$ \\
\hline
\end{tabular}

Means in each column followed by the same letter are not significantly different at the $5 \%$ level.

NS =Insignificant.

Concerning HFD/low STZ induction, data in Table (6) showed that HFD/STZ feeding diet without fenugreek significantly increased TC and LDL-c levels as compared with normal control .The other feeding treatments resulted insignificant effect on TG, HDL-c and vLDL-c. HFD/STZ fed on fenugreek soaked seeds diet (T3) decreased significantly TC $(75.25 \mathrm{mg} / \mathrm{dl})$ compared with HFD/STZ control $(84.87 \mathrm{mg} / \mathrm{dl})$ as well as HFD/STZ feeding with etiolated (T3) $(91.5 \mathrm{mg} / \mathrm{dl})$ or microgreen fenugreek (88.50 mg/dl). However, feeding HFD/DTZ with etiolated fenugreek sprouts (EFS T3) recoded significantly the higher TG (119 $\mathrm{mg} / \mathrm{dl})$, LDL-c $\quad(14.25 \mathrm{mg} / \mathrm{dl})$ and vLDL-c ( 23.97 $\mathrm{mg} / \mathrm{dl}$ ) levels compared with other treatment. The feeding with microgreen(T4) increased HDL-c $(52.50 \mathrm{mg} / \mathrm{dl})$ compared with standerd diet but feeding with boiled soaked seeds and etiolated sprouts recorded significantly the lower HDL-c levels compared with microgreen and normal control.

Table 6. Effect of fenugreek semi-modified diets on lipid profile of experimental rats without cypermethrin as pesticide

\begin{tabular}{|c|c|c|c|c|c|}
\hline Parameter & $\begin{array}{c}\text { Total } \\
\text { cholesterol } \\
\text { mg/dl }\end{array}$ & $\begin{array}{c}\text { Triglyceride } \\
\text { mg/dl }\end{array}$ & $\begin{array}{l}\text { HDL-c } \\
\mathrm{mg} / \mathrm{dl}\end{array}$ & $\begin{array}{l}\text { LDL-c } \\
\text { mg/dl }\end{array}$ & vLDL-c mg/dl \\
\hline Standard diet (T0) & $69.50 \mathrm{~B}$ & $95.50 \mathrm{~B}$ & $48.25 \mathrm{~B}$ & $5.75 \mathrm{C}$ & $19.50 \mathrm{~B}$ \\
\hline HFD/STZ (T1) & $84.87 \mathrm{~A}$ & 109.125B & $47.125 \mathrm{BC}$ & $14.25 \mathrm{~A}$ & $21.82 \mathrm{AB}$ \\
\hline $\mathbf{T} 2$ & $75.25 \mathrm{~B}$ & 103.250B & $45.625 \mathrm{C}$ & 7.375BC & $20.65 B$ \\
\hline T3 & $91.50 \mathrm{~A}$ & $119.815 \mathrm{~A}$ & $45.625 \mathrm{C}$ & $14.25 \mathrm{~A}$ & $23.97 \mathrm{~A}$ \\
\hline $\mathbf{T 4}$ & $88.50 \mathrm{~A}$ & $97.500 \mathrm{~B}$ & $52.50 \mathrm{~A}$ & $9.28 \mathrm{~B}$ & $19.50 \mathrm{~B}$ \\
\hline LSD at 0.05 & 7.744 & 15.128 & 21.612 & 2.071 & 3.026 \\
\hline
\end{tabular}

Means in each column followed by the same letter are not significantly different at the $5 \%$ level

$\mathrm{NS}=$ in significant

Regarding to the interaction between the CM pesticide and low dose STZ feeding with high fat diet treated by fenugreek semi-modified diets, data in Table (7) showed lower TC content for normal control than HDF/STZ control, while fenugreek etiolated sprouts and microgreen semi-modified diet ingested by $\mathrm{CM}$ pesticide recorded higher TC levels than that of normal control. However, CM pesticide interact with HFD and low dose STZ fed on etiolated fenugreek sprouts semi-modified diet decreased TG, LDL-c and vLDL-c levels compared with those of normal control.

The microgreen fenugreek semi-modified diet interacted with or without $\mathrm{CM}$ ingestion recorded higher HDL-c levels than the other treatments.

Table 7. Effect of fenugreek semi-modified diets on lipid profile of experimental rats

\begin{tabular}{ccccccc}
\hline Proup & Paramter & $\begin{array}{c}\text { Total cholesterol } \\
(\mathbf{m g} / \mathbf{d l})\end{array}$ & $\begin{array}{c}\text { Triglyceride } \\
(\mathbf{m g} / \mathbf{d l})\end{array}$ & $\begin{array}{c}\text { HDL-c } \\
(\mathbf{m g} / \mathbf{d l})\end{array}$ & $\begin{array}{c}\text { LDL-c } \\
(\mathbf{m g} / \mathbf{d l})\end{array}$ & VLDL-c (mg/dl) \\
\hline Group 1 & (POT0) & $69.75 \mathrm{e}$ & $100.75 \mathrm{bc}$ & $46.00 \mathrm{de}$ & $5.25 \mathrm{de}$ & $20.15 \mathrm{cb}$ \\
Group 2 & (POT1) & $84.75 \mathrm{bc}$ & $112.30 \mathrm{bc}$ & $47.00 \mathrm{cde}$ & $.6 .00 \mathrm{de}$ & $22.45 \mathrm{cb}$ \\
Group 3 & (POT2) & $73.50 \mathrm{ed}$ & $92.25 \mathrm{c}$ & $51.00 \mathrm{ab}$ & $3.75 \mathrm{e}$ & $18.45 \mathrm{c}$ \\
Group 4 & (POT3) & $84.00 \mathrm{bcd}$ & $140.75 \mathrm{a}$ & $43.75 \mathrm{ef}$ & $22.00 \mathrm{a}$ & $28.15 \mathrm{a}$ \\
Group 5 & (POT4) & $86.00 \mathrm{bc}$ & $94.25 \mathrm{bc}$ & $94.25 \mathrm{bc}$ & $53.75 \mathrm{a}$ & $10.75 \mathrm{bc}$ \\
Group 6 & (PT0) & $85.00 \mathrm{bc}$ & $94.25 \mathrm{bc}$ & $50.50 \mathrm{abc}$ & $6.25 \mathrm{de}$ & $18.85 \mathrm{cb}$ \\
Group 7 & (PT1) & $69.25 \mathrm{e}$ & $106.00 \mathrm{bc}$ & $47.25 \mathrm{cde}$ & $23.25 \mathrm{a}$ & $21.20 \mathrm{cb}$ \\
Group 8 & (PT2) & $77.00 \mathrm{e}$ & $114.25 \mathrm{~b}$ & $40.25 \mathrm{f}$ & $11.00 \mathrm{~b}$ & $22.85 \mathrm{~b}$ \\
Group 9 & (PT3) & $99.00 \mathrm{a}$ & $99.00 \mathrm{bc}$ & $47.50 \mathrm{bcd}$ & $6.50 \mathrm{de}$ & $19.80 \mathrm{cb}$ \\
Group 10 & (PT4) & $91.00 \mathrm{ab}$ & $100.75 \mathrm{bc}$ & $51.25 \mathrm{a}$ & $7.82 \mathrm{~cd}$ & $20.15 \mathrm{cb}$ \\
\hline LSD at 0.05 & & 10.951 & 21.94 & 3.6935 & 2.929 & 4.2787 \\
\hline
\end{tabular}

Means in each column in each group followed by the same letter are not significant different at the $5 \%$ level

$\mathrm{NS}=$ not significant 
The abnormal high concentration of serum lipids in fenugreek etiolated sprouts-semi-modified diet feeding for HFD/STZ rats may be due to mainly to an increase in the mobilization of free fatty acid from the peripheral fat depots, since insulin inhibits the hormone-sensitive lipase as reported by Pushparaj et al., (2000). Excess fatty acids in serum of diabetic rats are converted into phospholipids and cholesterol in the liver (Murray et al., 2012). These two substances along with excess triglycerides formed at the same time in the liver may be discharged into the blood in the form of lipoproteins (Bopanna et al., 1997).

From the above methodical results, it can be concluded that soaked fenugreek seeds can use as antidiabetic, antiobesity and antitoxicity agents against the harmful of STZ/ HFD combined with cypermethrin induction.

\section{References}

Abdallah, M.M.F. 2008.. Seed sprouts apharaoh's hertitage to improved food quality. Arab Univ. J. Agric. Sci., 16(2): 469-478.

Abdel-Mobdy, Y.E. and Abdel-Rahim, E.A. 2015. Toxicology influences of lambda cyhalothin and evaluation of the toxicity ameliorative effect of pomegranate in albino rats. Global Veterinaria, 14(6): 913-921.

Abdel-Rahim, E.A.; El-Beltagy, H.S.; Gaber, F.A. and Mahmoud, A.I. 2009. Alleviaton and improvement of hyperlipidimea in hypercholesterolemic rats by lentil seeds and apple as well as parsley as semi-modified diets. J. Biol. Chem., Environ. Sci., 4(2): 695-720.

Aldana, L.; Tsutsumi, V.; Craignill, A.; Silveria, M.I and Meijia, E.G., 2001. Alpha tocopherol modulates liver toxicity of pyrethroid. Cyoermethrin. Toxicol. Lett., 25: 107-116.

Allain, C. C.; Poon, L. S.; Chan, C. S.; Richmond, W. F. P. C., and Fu, P. C. 1974. Enzymatic determination of total serum cholesterol. Clin. Chem.., 20(4): 470-475.

Amer, M.;El-Habibi,E.S. and El-Gendy,A. 2004. Effect of trifolium alexandrinum extraction streptozotosin-induced diabetes in male rats.Annal. Nutr. Metab., 48(5): 343-347.

Belfiore, F. and Iannello, S. 1998. Insulin resistance in obesity: metabolic mechanisms and measurement methods. Mol. Gen and metabolism, 65(2): 121-128.

Bopanna, K.; Kannan, J.; Sushma, G.; Balaram, P.,and Rathod, S. 1997 . Antidiabetic and antihyperlipaemic effect of neem seed kernel powder on alloxan diabetic rabbits. Indian J. Pharmacol., 29: 162-167.

Dixit, P.; Ghaskadbi, S.; Mohan, H. and Devasagayam, T. P. 2005. Antioxidant properties of germinated fenugreek seeds.
Phytotherapy Research: An International Journal Devoted to Pharmacological and Toxicological Evaluation of Natural Product Derivatives, 19(11), 977-983.

Dzowela, B.H.; Hove, L. and Mafongoya, P.L. 1995. Effect of drying method on chemical composition and in vitro digestibility of multipurpose tree and shrub fodders. Tropical Grasslands. 29: 263-269.

European Commission 1996. Directive 96/54/EC: adapting to technical progress for twenty second time council directive 67/548/EEC on the approximation of laws, relating to the classification, Annex IVD: B.7. Repeated Dose (28 Days) Toxicity (oral).

Friedewald, W. T.; Levy, R. I. and Fredrickson, D. S. 1972. Estimation of the concentration of low-density lipoprotein cholesterol in plasma, without use of the preparative ultracentrifuge. Clin. Chem., 18(6): 499-502.

Fossati, P. and Prencipe, L. 1982. Serum triglycerides determined colorimetrically with an enzyme that produces hydrogen peroxide. Clin. Chem., 28(10): 2077-2080.

Giray, B., Gurbay, A. and Hincal, F. 2001. Cypernethrin induced oxidative stress rat brain and liver is prevented by vitamin E or allopurinol. Toxicol. Lett., 118: 139-146.

Ishmael, J. and Litchfield, M. H. 1988. Chronic toxicity and carcingenic evaluation of permethrin in rats and mice. Toxicol. Sci., 11(1): 308-322.

Iwanishi, M. and Kobayashi, M. 1993. Effect of pioglitazone on insulin receptors of skeletal muscles from high-fat-fed rats. Metabolism, 42(8): 1017-1021.

Jensen, R. 1992.. Fenugreek overlooked but not forgotten. UCLA Lactation Alumni Newsletter, 1: 2-3.

Kaviarasan, S.; Ramamurthy, N.; Gunasekhan, P.; Varalakshmi E. and Anuradha, C.V. 2006 - Fenugreek (Trigonella foneum graecum) seed extract prevents ethanol induced toxicity and apoptosis in change lever cells. Alcohol., 4: 267273.

Manna, S.; Bhattacharya, D.; Mandal, T.K., and Das, S. 2005. Reported dose toxicity of deltamethrin in rats. Indian Pharmacol., 37: 160-164.

Mansor, L.S.; Gonzalez, R.; Cole, M.A.; Tyler, D.J.; Beeson, J.H.; Clarke, K.; Carr, C.A. and Heather, L.C. 2013. Cardiac metabolism in a new rot model of type 2 diabetes using high fat diet with low dose streptozotocin. Cardiov. Diabetol., 12: 136-145.

Misra, S., and Sharma, C. B. 1997. Metabolism and bioaccumulation of fenvalerate and its metabolites in rat organs. Biomed. Chromatog., 11(1): 50-53. 
Murray,R.K.;Bender,D.A;Bothan,KM.;Kennell,P J;Rodwell,V.W.and Weil,P.A 2012 . Harpers illustrated biochemistry $27^{\text {th }}$ ed.Mc-Graw.Large Medical Book Hill Education Casia., 70-101.

Naidu, M. M.; Shyamala, B. N.; Naik, J. P.; Sulochanamma, G., and Srinivas, P. 2011. Chemical composition and antioxidant activity of the husk and endosperm of fenugreek seeds. LWT-Food Sci. and technol., 44(2): 451-456.

Portha, B.; Giroix, M. H.; Serradas, P.; Morin, L.; Tormo, M. A. and Bailbe, D. 1994. Cellular basis for glucose refractoriness of pancreatic Bcells in non insulin dependent diabetes. Insulin secretion and pancreatic $B$ cell research. UK: Smith-Gordon., 461-472.

Prasanna, M. 2000 . Hypolepidemic effect of fenugreek a clinical study. Indian J. Pharmacol., 32: 34-36.

Pushparaj, P.; Tan, C.H. and Tan, B.K.H. 2000 . Effect of Averrhoa bilimbi leaf extract on blood glucose and lipids in streptozotoxin diabetic rats. J. Ethnopha., 72(1): 69-76.

Raghuram, T. C.; Sharma, R. D.; Sivakumar, B., and Sahay, B. K. 1994 . Effect of fenugreek seeds on intravenous glucose disposition in non-insulin dependent diabetic patients. Phytotherapy Res., 8(2): 83-86.

Randhir, R.; Yuan T.L. and Shetty K. 2004 . Phenolics their antioxidant and antimicrobial activity in dark germinated fenugreek sprouts in response to peptide and phytochemical elicitors. Asia Proc. J. Clin. Nutr., 13: 295-397.

Ravikumar, P. and Anuradhna, C.V. 1999. Effect of fenugreek seed on blood lipid peroxidation and antioxidants in diabetic rat. Phytotherapy Res., 13: 197-201.

Reaven, G.M. and Ho, H. 1991. Low dose streptozotozotocin induced diabetes in the spontaneously hypertensive rat. Metabo., 40 : 335-7.

Rosholt, M. N.; King, P. A., and Horton, E. S. 1994 . High-fat diet reduces glucose transporter responses to both insulin and exercise. Am. J. of Physiol.-Regul., Integrative and Compara. Physiol., 266(1): 95:101.

Salah, S. H.; Abdou, H. S. and Abdel- Rahim, E. A. 2010 . Modulatory effect of vitamins A, C and $\mathrm{E}$ mixtures against tefluthrin pesticide genotoxicity in rats. Pesticides. Biochem. and physiol., 98(2): 191-197.

Sauvaire, Y.; Petit, P.; Broca, C.; Manteghetti, M.; Baissac Y.; Fernande Z.; Alvarez J.; Gross, R.; Roye, M.; Leconte A., Gomis, R. and Ribers, 1998 . G4-hydroxyisoleucine: a novel amino acid potentiator of insulin secretion. Diabetes., 47(2): 206-210.
Schoenig, G.P. 1995 . Mammalian toxicology of pyrethrum extracts. In: Casuda J.E., Quistad G.B. (eds) pyrethrum flowers: production, chemistry, toxicology and uses New York: Oxford University, press., 249-257.

Shafrir, E. 2003. Diabetes in animal: Contribution to the understanding of diabetes by study of its etiopathology in animal model. In Porte D., Sherwin RS, Baron A, editors. Diabetes Millitus. New York: McGrow-Hill., 231-255.

Schermer, S. 1967. The blood morphology of laboratory animal. 3ra. FA Davis Company, Philadelphia.

Singh, K. P.; Nair, B., and Naidu, A. K. 2013. Contribution of fenugreek (Trigonella foenum graecum $L)$ seeds towards the nutritional characterization. J. of Med. plants. Res., 7(41): 3052-3058.

Snedecor, G.W. and Cochran, W.G. 1980. Statistical Methods. $7^{\text {th }}$ ed. Iowa State University Press, Ames, Iowa, USA. Pp. 507.

Srinivasan, K.; Patole, P.S.; Kaul, C.L. and Ramarao, P. 2004 . Reversal of glucose intolerance by pioglitazone in high-Fat diet fed rats. Methods Find Exp. Clin. Pharmacol., 26: 327-333.

Srinivasan, K.; Viswanad B.; Asarat L.; Kaul, C.L. and Ramarao, P. 2005 . Combination of high fat diet fed and low dose streptozotocin treated rat: a model for type 2 diabetes and pharmacological screening. Pharmacol . Res., 52(4): 313-320.

Storlien, L.H.; James, D.E.; Burleigh, K.M.; Chishdm, D.J.,and Kraegen, E.W. 1986 . Fat feeding causes widespread in-vivo insulin resistance, decreased energy expenditure and obesity in the rat. Am. J. Physiol., 251: E576-583.

Tahany, A.A.Aly. 2015 . Biochemical studies of antidiabetic effects of some seed sprouts in adult male albino rats.Ph.D.Thesis.Dept. of Biochem. Fac. of Agric. Cairo, University, Egypt.

Taniguchi, H.; Muroi, R.; Kobayashi-Hattori, K.; Uda, Y.; Oishi, Y. and Takita, T. 2007. Differing effects of water-soluble and fat-soluble extracts from Japanese radish (Raphanus sativus) sprouts on carbohydrate and lipid metabolism in normal and streptozotocin-induced diabetic rats. J. of nutr. sci and vitaminol, 53(3): 261-266.

Trinder, P. 1969 . Determination of blood glucose using anoxidation peroxidase system ${ }^{13}$ with a non carcinogenic chromogene. Ann. Clin. Biochem., 6: 24.

Verschoyle, R.D. and Aldrige, W.N. 1980 .Structure activity relationships of some pyrethroids in rats. Arch. Toxicol., 45: 325-329. 


\section{تاثير الحلبة علي التمثيل الغذائي للكريوهيدرات والدهون في الجرذان المعاملة بالسيبرمثرين مع التظذية عالية الدهون والمحقونة بجرعة منخفضة من الاستريتوسيتوزين

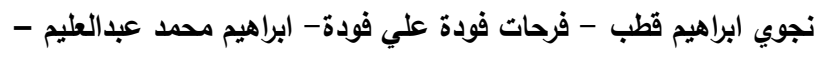 \\ ياسمين امام عبد المبدي - تهاني عبدالففار احمد علي}

تهدف هذه الدراسة لإستخدام النموذج الجديد لمرض السكري من النوع الثاني باستخدام التغذية مرتفعة الدهون بالاثتراك مع الجرعة المنخفضة

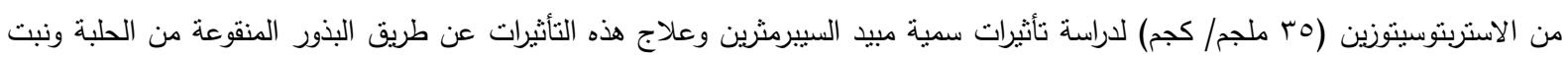
الظلام بعدر ثلاثة أيام والبادرات الخضراء بعمر عثرة أيام كجزء من مكونات عليقة نصف معدلة للجرذان المصابة. استخدام التغذية مرتفعة الدهون مع الجرعة المنخفضة في الاستربتوسيتوزين والمعاملة مع مبيد السبيرمثرين أدت إلى زيادة في مستوى السكر في الدم وزيادة الليبوبروتين

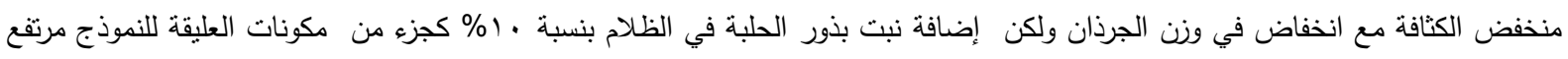
الدهون مع الجرعة المنخفضة من الاستربتوسيتوزين أدى إلى زيادة معنوية في وزن الجرذان والزيادة المكتسبة للوزن والكوليسترول الكلي

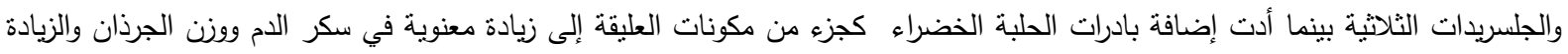
المكتسبة في الوزن والكوليسترول الكلي والليبوبروتين مرتفع الكثافة ولكنها أدت إلى إنخفاض الليبوبروتين منخفض الكتافة ومن ناحية أخرى أدت أدان

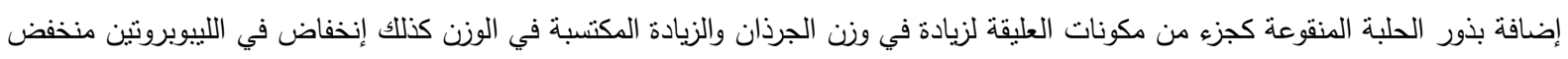

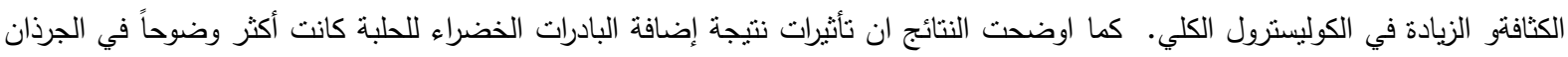

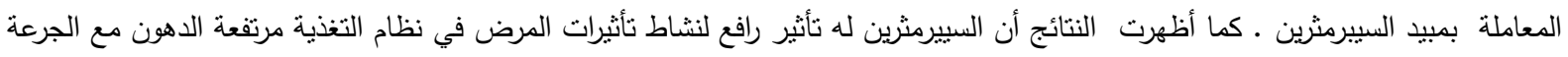
المنخفضة مع الاستربتوسينوزين بينما إضافة بذور الحلبة المنقوعة أدت إلى تحسين التمثيل الغذائي للدهون بالمقارنة مع نبت الظلام و البادرات الخضراء للحلبة كجزء من مكونات العليقة . ويمكن التوصية من هذه الدراسة بأن بذور الحلبة المنقوعة يمكن استخدامها كمواد مضادة لمرض السكري ومكافحة السمنة وكذلك مضادة للسمية في نظام التغذية مرتفعة الدهون مع الجرعة المنخفضة من الاستربتوسيتوزين والمرتبطة مع احداث مبيد السيبرمثرين ـ كماتضح اتضح ان النسبة المضافة من الحلبة للعليقة أنها غير سامة في الجرعة المستخدمة للجرذان لمدة بـ ب يوم وهى فترة الدراسة. 